\title{
A Presença do Petróleo nos Estados Unidos: O Hidrocarboneto na História de uma Grande Potência
}

\author{
The Presence of Oil in the United States: \\ The Hydrocarbon in the History of a Great Power
}

José Alexandre Altahyde Hage ${ }^{1}$

Resumo: O objetivo deste ensaio é fazer um simples balanço do petróleo na história recente dos Estados Unidos. Isto porque o mais importante recurso energético não é desligado da história da principal potência internacional. Analisar a história do petróleo é se voltar para a compreensão dos Estados Unidos desde a segunda metade do século XIX até os anos 1990, quando não houve nenhuma potência com vigor suficiente para contestar o poder americano.

Palavras-chave: Geopolítica do Petróleo; Política Internacional; História da Energia.

Abstract: The purpose of this essay is to present a simple balance of oil in the recent history of the United States. This relevant energy resource is not disconnected with the history of the main international power. To analyze the history of oil is to get back to the understanding of the United States since the second half of the $19^{\text {th }}$ century till the $1990 \mathrm{~s}$, when there was no other power strong enough to contest US power.

Keywords: Geopolitics of Oil; International Politics; History of Energy

(cc) EY Direito autoral e licença de uso: Este artigo está licenciado sob uma Licença Creative Commons. Com essa licença você pode compartilhar, adaptar, para qualquer fim, desde que atribua a autoria da obra, forneça um link para a licença, e indicar se foram feitas alterações. 


\section{A Invenção Americana do Petróleo}

Ao dizermos que foi nos Estados Unidos onde se inventou o petróleo o fazemos de modo metafórico. O que a iniciativa empresarial norte-americana fez foi dar os passos iniciais para que houvesse posteriormente uma pujante indústria petrolífera em todo o mundo. Isto porque, de um modo ou de outro todos os países guardam interesse no ouro negro. Mesmo aqueles que procuram autossuficiência energética não descuidam da economia do carburante em virtude da influência que ele tem nas finanças internacionais.

Como tem sido comum observar na "cultura empresarial" norteamericana, sobretudo nas duas últimas décadas do século XIX, o petróleo se transforma em bem econômico em virtude de maquinações individuais de pessoas que procuraram fazer fortuna rápida. Já faz parte do folclore dos Estados Unidos aventureiros que utilizavam de prestidigitações para enganar incautos que também queriam acumular dinheiro no mais rápido tempo. $^{2}$

No caso do petróleo não foi de outra forma. Conhecido pelos antigos índios do meio-leste norte-americano para fazer fogo e outras utilidades locais o óleo passa a chamar atenção de um "típico" capitalista estadunidense: capitão Edwin Drake. Por volta de 1865 Drake, que não era militar, mas usava a patente para impressionar, encontra petróleo no estado da Pensilvânia e logo isola o terreno para prospecção e comércio do carburante. ${ }^{3}$

A fama da exploração petrolífera como meio certo de enriquecimento se espalha rapidamente e chama atenção de inúmeros investidores e aventureiros para maximizarem lucros com o produto. A criação instantânea de riqueza ocorre nas mãos do capitão e mais alguns apaniguados. Porém, em menos de uma década, o maná se esgota a ponto de não ser mais viável para a atração popular e obter novos recursos financeiros para crescer.

Os motivos para tanto não são desconhecidos. As técnicas de exploração são rudimentares e não evitam o desperdício. Em outros tempos, mesmo com o esgotamento de determinados poços ainda assim seria possível obter mais petróleo, mas com a ausência de capacidade na época o excedente não podia ser prospectado. Outro motivo para abreviar a vida produtiva daquelas fontes era a utilidade para qual se dava à matéria-prima.

O principal uso do petróleo era para iluminação pública. Para isso, refinava-se o óleo para obter querosene. Em uma época em que a iluminação pública, da Nova Inglaterra, por exemplo, era dependente da caça à baleia, e sua extração de óleo para lamparinas, a invenção do querosene teve coloração revolucionária para aquele setor econômico. ${ }^{4} \mathrm{~A}$ febre do novo meio de iluminação denotava conforto para os consumidores, facilidade para os comerciantes e riqueza para os produtores. Por conseguinte, tudo que não era utilizado para ser querosene tinha fim no despejo em rios e poços específicos, até a gasolina. 
Por outro lado, não seria lícito historiar o aparecimento comercial do petróleo sem levar em conta o que houve na Rússia poucos anos depois. Mesmo que a história do óleo seja mais conhecida em todo o mundo, em virtude do apelo empresarial que houve no Ocidente, não se pode deixar de mencionar os acontecimentos na região de Baku, Azerbaijão que, a exemplo da corrida do ouro na Califórnia e no Alasca, atraiu grande número de investidores para fazer fortuna naquela parte do império czarista. Talvez o mais conhecido desses jogadores do incerto tenha sido Alfred Nobel que ao negociar dinamite, TNT, para a abertura de poços acumulou riqueza a ponto de fazer depois sua famosa fundação. ${ }^{5}$

Paralelo à sorte de Nobel, e seus agregados, outra célebre família procurou lucrar em Baku: os Rothschilds, com serviços bancários e de financiamento de obras da infraestrutura petrolífera. A explicação para o malogro da produção russa não estaria longe da norte-americana do momento. Contudo, um elemento a mais ajuda a diferenciar o acontecimento: as crises políticas que alimentaram o processo revolucionário que desembocará no enfraquecimento do czarismo, pela Revolução de 1905, e sua conclusão no Outubro de 1917.

Todavia, como se registra na cronologia internacional do empreendimento, a preeminência é norte-americana. O grande nome que se confunde com a história do petróleo nos Estados Unidos é o de John D. Rockfeller. Em 1870 esse comerciante de armarinhos, ou de ferragens, de pouca escolaridade, mas com facilidade para fazer negócios, se interessa pela diversificação de ganhos no novo eldorado petrolífero, o de Oklahoma.

É certo que não se trata de fazer, neste ensaio, história de personalidades ou hagiologia, sem oferecer fundamento político na análise. Contudo, pode ser apressado adentrar à história do petróleo nos Estados Unidos sem mencionar a figura de John Rockfeller, pois a moderna indústria do insumo, querendo ou não, tem início com esse empreendedor.

Ao deixar o ramo de varejo Rockfeller investe na prospecção de novas jazidas em Oklahoma. Passa ele a comprar a produção de pequenos poços, espalhados pelo estado, e concentrá-los em um depósito de sua propriedade, iniciando um tipo de centralização das operações. Esse é o salto organizacional desse empresário que procura uniformizar a compra de óleo e sua estocagem. Sua intenção é manter um grau de qualidade e eficiência na distribuição. O resultado disso é a fundação da maior empresa petrolífera do mundo, a Standard Oil Company, na década de 1870. Logo depois, em 1890, a Standard foi pulverizada originando outras firmas menores em virtude da lei antitruste dos Estados Unidos. ${ }^{6}$

Momentos antes da dissolução da megaempresa a Standard dominava perto de $90 \%$ do mercado petrolífero dos Estados Unidos e dividia o lado internacional com outro gigante, a europeia Royal Dutch Shell, conforme 
leitura de Yergin. ${ }^{7}$ Quais foram os instrumentos utilizados por Rockfeller para fazer de sua firma a dominante setorial antes da lei antitruste?

Tivemos oportunidade de frisar que um dos meios para tanto foi a uniformização do produto, procurando obter qualidade das fontes produtores. Outros meios foram incorporados, como a entrada da própria Standard na produção de óleo ao comprar as jazidas menores. Por fim, o americano concluiu seu intuito ao substituir ferrovias de outros empresários por suas, bem como utilizar outros métodos, como o escoamento via duto. No final do século XIX Rockfeller dominava todo o setor de petróleo dos Estados Unidos.

Com o fim da denominação Standard Oil Company pela Lei Sherman Rockfeller foi obrigado a dividir a empresa em sete partes, algumas conservando o nome com a complementação do estado onde ela atuava. A operadora de Nova York passou a se chamar Standard Oil of New York. A de maior dimensão e sucesso empresarial chamou-se Standard Oil of New Jersey, cuja evolução e posterior concentração sobre as irmãs menores deu origem a Exxon Corporation em 1972, a maior empresa petroleira do mundo.

E por que o petróleo foi alçado ao papel de principal insumo do século XX? Não há condições de demorar neste texto para explicar com pertinência os motivos. No entanto, podemos sublinhar que o advento paulatino do petróleo na economia internacional do século passado teve gênese nos Estados Unidos em virtude de sua comodidade e baixo preço quando comparado ao carvão mineral. Outro impulso certamente se deu por causa da explosão do transporte individual logo na primeira década do século XX. O carro particular, o simbólico Ford modelo T, abriu um mercado para consumidores da classe média.

A conveniência pela iluminação a querosene ou lubrificantes melhores já seriam assuntos esgotados perante um rol de interesses e invenções propiciadas pela indústria petrolífera. O monumental emprego do carburante na vida moderna, sobretudo norte-americana, impulsionou um novo estilo de vida, uma nova cultura econômica e social que, de algum modo, fomentou a dependência que as potências do Hemisfério Norte teriam com o carburante.

A massificação do carro particular ao alcance do trabalhador comum, o planejamento de bairros elegantes no subúrbio dos grandes centros urbanos, também podendo ser comprados por quem trabalhasse regularmente, e a invenção da petroquímica, com plástico, fertilizantes agrícolas etc, contribuíram para o advento da dependência ao ouro negro. Daí, a dramatização que o tema leva às questões de política internacional.

\section{O Petróleo na Primeira Guerra}

A substituição do carvão mineral pelo petróleo se deu de modo paulatino e podemos dizer que ainda não terminou. Esse fato ocorre tanto nos Estados Unidos quanto na China, os dois maiores consumidores do insumo. Ao adentrar na primeira década do século XX fica patente que o emprego 
dos hidrocarbonetos tende a aumentar constantemente na economia norteamericana em virtude dos temas citados neste ensaio. Além deles havia também o emprego do óleo combustível que concorreria e ultrapassaria o uso do carvão em caldeiras e na nova geração de navios da Marinha de Guerra.

Aliás, a substituição do carvão pelo combustível fóssil na marinha britânica merece comentários mais detalhados. Por volta de 1910, no ápice do esforço alemão em obter respeitável armada com objetivo de concorrer com a do Reino Unido, até então a mais poderosa, aparece sinal de alerta para o Almirantado Britânico, sob autoridade de Winston Churchill. O famoso político levou para o debate público a necessidade de haver substituição, com urgência, de grande parte dos navios da Royal Navy por mais modernos.

A modernidade nos navios significa que a Alemanha, ao contar com sua excelência em engenharia e ciência, passa a substituir unidades movidas a carvão pelas mais novas, a óleo diesel. O emprego desse novo motor permite rapidez e vantagem estratégica maiores que os antigos navios - sem contar a economia de custos e de homens que poderiam ser empregados em setores mais proveitosos em outras atividades militares navais.

Como não podia ser de outra forma, Churchill alerta a elite politica britânica sobre a novidade vinda da Alemanha, a franca competidora do poder britânico. Dúvidas e impasses imperaram sobre assunto tão delicado a ponto de se saber se o grande líder estava certo em seu empenho. O motivo para isso não seria sem propósito; afinal, a Grã-Bretanha tem enormes reservas de carvão mineral, suficientes para a Marinha. Mas quem tem petróleo? Na época, pobre em hidrocarbonetos Londres receava trocar a segurança do carvão, ainda que ultrapassado, pela novidade praticamente ausente nas ilhas britânicas.

A busca pelo petróleo deveria ser assegurada no império colonial, mais precisamente na Pérsia. Mesmo assim, o alerta não se findou porque a distância entre o Oriente Médio e a Grã-Bretanha não apagava o perigo de serem os navios mercantes atacados por marinhas inimigas, leia-se alemã. E isso daria à Armada britânica mais trabalho que poderia suportar, uma vez que ela teria de controlar mares e proteger embarcações civis.

Com o advento da Primeira Guerra Mundial acontece a parceria estratégica, anglo-americana, cuja duração chega à atualidade. De potências desconfiadas no século XIX Estados Unidos e Grã-Bretanha firmam aliança entre suas marinhas em face do poder naval alemão, sobretudo. Desta forma, cabe a Washington assegurar o suprimento de petróleo necessário à Marinha britânica que passa a ser equipada com motor a diesel; Churchill consegue convencer a elite politica de seu país sobre a preeminência do novo combustível.

Os Estados Unidos eram os maiores produtores e consumidores de óleo nos anos daquela guerra. Ao ter o território praticamente incólume de ataques estrangeiros, e poder contar com a parceria britânica, o país norte-americano pode garantir o petróleo necessário aos Aliados, uma vez que as forças alemãs 
torpedeavam navios mercantes entre o Oriente Médio e a Europa Ocidental. Sem poder contar com a ajuda da União Soviética, rica no insumo, mas impedida pela guerra com a Alemanha coube aos Estados Unidos a responsabilidade de assegurar o suprimento de óleo no clima difícil daquele conflito internacional. Reflete Yergin: "Agora que o acesso à Rússia havia sido fechado pela guerra e pela revolução, o Novo Mundo tinha se tornado o celeiro do Velho; no total os Estados Unidos entravam com $80 \%$ das necessidades bélicas de petróleo dos Aliados". 8

A partir da guerra ficaria patente que o emprego de hidrocarbonetos seria sem volta. Locomotivas, a invenção do tanque de combate, o uso de caminhões, navios em geral seriam todos movidos a petróleo. Tudo isso contribuiria para aquilo que Hobsbawn denomina guerra total, em que não fica mais claro o que é setor civil e o que é economia de guerra, visto que uma refinaria pode tanto produzir combustíveis para o comercio quanto para as forças armadas. ${ }^{9}$ Portanto, atacar uma refinaria seria também um ato estratégico.

Em outra instância, ficaria patente que na constituição e análise sobre o poder nacional de um determinado Estado deveria se considerar o quanto de energia essa unidade política produziria. Em outras palavras, junto com produção industrial, qualidade das forças armadas, demografia e agricultura entraria também na contabilidade a capacidade do país de produzir combustíveis, bem como seu emprego no exercício da guerra.

Os Estados Unidos reforçariam a escalada do petróleo como combustível principal junto ao carvão mineral em seu território. A mesma situação pode ser lida na Europa Ocidental, ainda que de forma não homogênea. Ficara patente que o uso dos hidrocarbonetos estava em estado acelerado nas economias norte-americana e algumas industrializadas do Velho Continente. Porém, não havia ainda chegado o momento de ser o petróleo o insumo de uso inconteste no mundo, pois existiam sociedades em que os combustíveis fósseis seriam desconhecidos ou de parco uso, caso da China e da Índia dos anos 1920. Mesmo na atualidade em muitas partes do Hemisfério Sul a queima de hidrocarbonetos não é superior a madeiras não tratadas ${ }^{10}$ e demais materiais orgânicos.

\section{O Intervalo entre Guerras}

Entre 1920 e 1940 houve mistura de euforia econômica com depressão. O petróleo fora saudado como boa nova para aqueles que adentravam a um novo estilo de vida, urbano e de invenções para facilitar o cotidiano. Começou a era do carro, do transporte individual que levou famílias a se mudarem para locais distantes dos centros urbanos. Apareceriam os bairros de classe média, os subúrbios de Nova York e Chicago, entre outros, que moldariam a paisagem dos Estados Unidos urbano, tornando-se exemplo do progresso.

Neste aspecto, não havia dúvidas de que a produção petrolífera estava na obrigação de crescer, para dar conta da enorme demanda. O problema que 
ganhou corpo tempos depois foi que não havia regulação governamental sobre o setor petrolífero nos Estados Unidos. Embora a antiga Standard Oil houvesse imprimido uniformização em seus produtos no final do século XIX a realidade do entre guerras era a de que o mercado estava anarquizado e a mercê das maiores companhias. Não eram somente as Sete Irmãs que nasceram do espolio da Standard; havia também um amontado de pequenas firmas. ${ }^{11}$

Isto porque, anos 1920, ocorre mudança do eixo produtivo nos Estados Unidos. A principal produção deixa de ser no norte e nordeste do país e passa para o novo centro petrolífero, o Texas. Para esse estado migram as antigas empresas do setor ou lá se estabelecem como novos empreendimentos, caso da Texas Company, braço da Standard chamado Texaco.

No campo da regulação setorial haverá o emprego da Texas Railroud Board que, por mais curioso que seja, será responsável pela regulação da produção texana - questões de conveniência que tem a ver com a legislação norte-americana. Por ser o Texas o maior produtor local de petróleo tudo que passa a ser do interesse do setor ganha dimensão política nacional. Por outro lado, a regulação federal propriamente dita, com poder político de algum nível, só aparece em 1941, no governo de Franklin Roosevelt, por causa da economia de guerra. Mais uma vez os Estados Unidos teriam de suprir o petróleo dos Aliados e por isso a centralização nas mãos de Washington, com controle da produção e do preço.

Já no âmbito internacional, em que o poder americano não se fazia sentir por causa de sua política externa introspectiva, a regulação sobre a demanda e preço do petróleo ficou em aberto até 1928. Sem um ente que sobressaísse às empresas nacionais, bem como aos seus governos, imperou uma corrida desenfreada em que a produção e a escalada de preço correspondiam ao ânimo em que havia no momento. Não havia, de fato, grande número de players no mercado internacional de energia em virtude dos desafios inerentes ao meio.

O que havia denotava ao meio externo um quê de paradoxal. Com poder de jogar no mercado internacional só havia duas empresas: o grupo da Standard Oil, as Sete Irmãs, que podiam trabalhar juntas ou individualmente, e a atual anglo-holandesa Shell. A Anglo-Persian (BP) só depois da Segunda Guerra conseguira musculatura para participar de jogo que se tornara pesado. E por que isso era paradoxal? Era assim porque, de um lado, não havia muitas firmas para controlar e procurar acordo. Mas de outro lado, por haver apenas duas, a situação ficava mais complicada, pois se trava das maiores e das mais fortes do mundo.

A resolução para uma situação de "terra de ninguém" teria de ser encontrada em firmes acordos entre não somente as empresas internacionalizadas, mas também aos governos nacionais, vale dizer, norte-americano e britânico. Deste modo, em 1928, outorgou-se o Encontro de Achnacarry, castelo na Escócia, em que se firmou compromisso suficiente para regular o setor de 
petróleo até os anos 1940, época em que forçosamente haveria controle sobre o setor, independente das vontades empresariais privadas. Aqui começa, de forma irregular, a ascensão do poder político sobre o campo de energia.

O tom que vemos nos anos 1930 vai do entusiasmo, da euforia aos impasses políticos que começam a ganhar corpo. Se o petróleo já era bem passível de politização em virtude da Primeira Guerra sua escala aumenta porque ele passa a ser também trunfo governamental e item de plataformas nacionalistas. Assim, deu-se na América Latina no ano de 1937.

Observamos que o Estado britânico havia criado, em 1909, a AngloPersian Oil Company, posteriormente British Petroleum (BP) para que essa fosse tivesse operação específica na Pérsia. Havia a premissa de que não se poderia confiar desmesuradamente em empresas privadas, cujos interesses são próprios ou em unidades internacionalizadas, multinacionais. A advertência sobre isso ficou claro por causa da simpatia que a presidência do lado holandês da Shell apresentava ao governo nazista da Alemanha. ${ }^{12}$

Em 1938 tudo isso deve ter contribuído para que dois países, diferentes em vários aspectos, nacionalizassem ativos estrangeiros em seu território: México e Argentina. O caso mais emblemático foi o México. Governado pelo programa nacionalista do presidente Cardenas o país retirou das empresas norte-americanas e britânicas ativos para que se formasse no mesmo tempo a estatal Petroleos de México - PEMEX.

Por estar tão perto dos Estados Unidos e tão longe de Deus, conforme observação angustiada do antigo presidente Benito Juares, a questão mexicana virou item exemplar. Menos dramática, por nunca ter sido uma importante produtora mundial de petróleo, a nacionalização feita na Argentina deu origem a Yacimientos Petroleos Fiscales - YPF. A empresa nos anos 1980 foi privatizada e reestatizada no começo dos anos 2000.

Neste ensaio foi mencionado acima o ponto segundo o qual a ascensão do poder político sobre a energia, especificamente petróleo, aparece em momentos distintos e desiguais. A Grã-Bretanha o convoca por causa das dificuldades de operação na Pérsia, inicialmente, e também em face da politização da Shell. Posteriormente o fenômeno avança no México e na Argentina. Por isso, não seria demais lembrar que a Segunda Guerra Mundial fará com que o Estado se estenda ao campo da energia de forma automática. Não se poderia mais separar o que é energia da conformação estratégica de uma potência.

\section{Petróleo na Segunda Guerra Mundial}

A partir desse último grande conflito todas as manifestações que os Estados Unidos fizeram no âmbito da política do petróleo passaram a ter dimensão internacional, mesmo quando o intuito do país era resolver alguma questão doméstica. Em outro diapasão, o Estado norte-americano não mais teve escolha de não tomar parte nos grandes impasses sobre o petróleo no 
mundo. Nos acontecimentos que resultaram em conflitos interestatais houve participação da política dos Estados Unidos ou de empresas petrolíferas americanas.

Se a guerra de 1914 recebeu grande impulso do petróleo na movimentação de máquinas já, na de 1939, o hidrocarboneto será essencial. É claro que não se trata de adotar reducionismo para dizer que a vitória dos Aliados contra o Eixo se deveu a reservas energéticas, dominadas pelos Estados Unidos e Grã-Bretanha, que inexistiram para Alemanha e Japão. Certamente, a derrota dessas duas potências também se deveu a outros fatores.

Apesar disso, não há como negar o papel que o petróleo, ou outro insumo energético, teve no desenrolar estratégico das potências do Eixo. $\mathrm{Na}$ Primeira Guerra a Alemanha pôde se abastecer de petróleo junto a reservas razoáveis que havia na Romênia, entre outras fontes menores. Na Segunda, a Europa Orientação não mais seria viável como fonte segura de abastecimento. Por isso, duas decisões estratégicas havia tomado o III Reich: dominar o Norte da África e abrir frente de combate na União Soviética.

A luta no continente africano significaria se apossar de reservas do Oriente Médio e, ao mesmo tempo, negar à Grã-Bretanha, sobretudo, acesso ao óleo que passaria pelo Canal de Suez, no Egito. Já a segunda empreitada, muito mais difícil, tinha o objetivo de fazer com que a Alemanha dominasse a tradicional zona de prospecção soviética, de Baku, que daria ao Eixo conforto energético para tocar a guerra no Ocidente..$^{13}$ :

O ataque a Pearl Harbor em 1941 foi uma resposta imediata do Japão ao embargo imposto pelos EUA, seu tradicional fornecedor. Com a destruição, naquela batalha, da frota americana do Pacífico, o Japão ficou livre para tomar os ricos campos de óleo da Indonésia, então colônia holandesa, sem correr o risco de sofrer, no curto prazo, uma retaliação militar dos EUA. Do mesmo modo, a invasão da União Soviética e do Norte da África pelos alemães visava o controle dos poços do Cáucaso e do Irã. ${ }^{14}$

O Estado norte-americano apresentava vantagem em energia ausente na Europa e no extremo leste. Até aquele momento os Estados Unidos continuavam sendo o maior produtor mundial de petróleo. Porém, a quantidade produzida não seria suficiente para dar conta das necessidades domésticas do país e ajudar na campanha de guerra dos Aliados. Com a economia de guerra, de alta industrialização e a dificuldades internacionais de transporte, o governo Roosevelt planejou políticas de impacto e de longa duração.

Com relação à América Latina, que tradicionalmente vivia sob forte desconfiança com o poder americano, Roosevelt imprimiu a famosa Diplomacia da Boa Vizinhança, cujo fito era aproveitar o superávit de petróleo do México 
para fins militares. No aspecto interno, a Casa Branca forçou a centralização política sobre a indústria do petróleo deixando claro que em situação de urgência o setor deveria ser subordinado às vicissitudes da poder. Disso nasce a política de controle de preços e de produção que a indústria petrolífera teria que atender. Tal ascendência duraria enquanto perdurasse a necessidade.

Por outro lado, em situações adversas, Alemanha e Japão teriam de desenvolver novos insumos, sintéticos, cujo balanço energético era bastante desequilibrado, isto é, para cada unidade de energia extraída era necessário o gasto de cinco ou mais de unidades de dinheiro. Cita-se, por exemplo, o óleo de carvão mineral. Embora economicamente tais iniciativas fossem condenadas a cultura tecnológica que elas lograram ajudariam a geração de novos combustíveis sintéticos que podem ter grande papel no futuro próximo.

O fim da Segunda Guerra promoveu mudanças substanciais na economia internacional da energia, inclusive de ordem geopolítica. Os Estados Unidos começam a perder dianteira na produção mundial de petróleo. Já se começa a vislumbrar a ascensão da Arábia Saudita e do Irã como promissores no mundo dos hidrocarbonetos. Uma das páginas marcantes na história do insumo e a posição norte-americana foi o encontro que o presidente Roosevelt teve com o futuro monarca da Arábia Saudita Ibn Saud, em 1945, no navio USS Quincy. Eis o Encontro do Quincy que selou a relação estratégica entre a República e o Reino.

No mesmo pé, dá-se também início ao processo de nacionalização dos ativos empresariais em países produtores e a fundação de empresas estatais, cujos efeitos políticos perduram até hoje. Aquilo que havia começado no México e Argentina se espalha como afirmação política em face da inserção econômica dos Estados Unidos e da Grã-Bretanha sobre o setor.

\section{O Nacionalismo Petrolífero e suas Crises}

O assunto petróleo, ou a ele relacionado, entra nos anos 1950 sob o signo do nacionalismo. Assim se deu o primeiro grande impasse entre um país importante na economia petrolífera com o mundo ocidental: a nacionalização do Canal de Suez, em 1956, pelo governo do coronel Gamal Nasser. Ressentido com os britânicos e franceses que os construiu, em 1869, a plataforma política nasserista nacionalizou a obra por acreditar que ela sangrava as riquezas egípcias. Isto porque, uma vez sob domínio anglo-francês o canal só repassaria ao Egito a menor parte da arrecadação geral, paga pelos navios.

No entanto, não eram somente embarcações mercantes que passavam pelo Suez; praticamente todos os navios petroleiros, carregados no Oriente Médio, os utilizava para chegar aos portos europeus e norte-americanos. Portanto, fechar aquela via significava boicotar óleo às potências industrializadas. E desta forma, se deu a primeira relevante crise de energia, de falta de suprimento de petróleo, com viés político contra as grandes potências. 
Sair daquele imbróglio não fora tarefa fácil, uma vez que seria contraproducente negar a nacionalização ao Egito, uma vez que o canal passava pelo seu território e, de fato, manter a preeminência anglo-francesa sobre aquela infraestrutura alimentaria um visão colonialista da qual os Estados Unidos não queriam conservar em face do fértil Movimento dos Não-Alinhados que começara a se formar no encontro de Bandung, em 1955. ${ }^{15}$

Por outro lado, negar direito a Londres e Paris também não seria conveniente, uma vez que se tratava de dois aliados fundamentais da Organização do Tratado do Atlântico Norte (OTAN) contra as manifestações geopolíticas da União Soviética. A resolução de Washington para sanar a questão do Canal de Suez não foi a mais simpática ou fácil, mas sim aquela mais conveniente para a atmosfera da Guerra Fria e um complicado Oriente Médio.

Os Estados Unidos, com a surpreendente concordância da União Soviética, aceitaram a nacionalização do canal e forçaram britânicos, franceses e israelenses a aceitarem também, quase de modo manu militari. Em princípio, pode-se dizer que aquela pressão não deixou de ser uma humilhação para duas grandes potências que em virtude de sua decadência não mais puderam fazer valer sua palavra sobre algo de exclusivo interesse. Neste quesito, Raymond Aron é da opinião de que a resolução americano-soviética exaltou a conveniência do equilibro no lugar da justiça internacional. ${ }^{16}$ Uma vez nacionalizado o canal voltou a funcionar normalmente, com pouquíssimas questões.

Outro forte distúrbio político se deu no Irã em 1952. Podemos observar que o Estado britânico havia feito a estatal, a Anglo-Persian Oil Company, para operar quase que exclusivamente o petróleo da Pérsia (Irã). Com o processo de soberania do país em face das grandes potências, minando seu caráter de protetorado, o Irã passa a ter como primeiro-ministro também alguém de feições nacionalistas, Mohammed Mossadegh, cujo primeiro ato foi a estatização da Anglo-Persian local. Homem formado em Direito na Suíça, mas que pensara da mesma forma que Nasser no Egito pregava a necessidade de se nacionalizar os bens internacionais para que houvesse condições de se obter um Estado sob o modelo ocidental.

Os motivos para a antipatia anglo-americana com os processos nacionalizantes do Oriente Médio não eram sem propósito. Uma coisa era suportar reviravoltas do México que, embora produtor de óleo, não configura na no primeiro time do assunto. Mas diferente deveria ser com o Irã, ou outro da região, cuja importância no mundo dos hidrocarbonetos não era pequena. Suportar o manifesto de Mossadegh poderia soar fraqueza em uma área pronta para testar os limites das potências ocidentais. E uma vez os Estados Unidos contemporizando com Teerã poderia ser prejudicial para sua projeção de poder.

Outro perigo iminente para a Washington e Londres seria a aproximação do Irã à União Soviética em busca de equilíbrio ou alguém para descarregar a 
tensão política, uma vez que o governo Mossadegh não teria forças suficientes para bancar sozinho aquela disputa em face de pressões domésticas e internacionais. Além disso, Mossadegh demonstrava simpatia por um partido político iraniano de características comunistas-soviéticas.

O trabalho titânico dos Estados Unidos e Grã-Bretanha foi afastar Moscou dessa empreitada e isolar o Irã. O resultado parece ter dado certo, uma vez que os serviços secretos americano e britânico envenenaram as relações internacionais de Mossadegh a ponto de derrubá-lo com um golpe de Estado em 1953. O desfecho foi a valorização de um governo amigo, reforçando o monarca Xá Mohammed Pahlev, este derrubado em 1979.

O balanço final da questão iraniana foi procurar a moderação pósMossadegh. Vale dizer, a nacionalização não foi desfeita, aceitou-se seus termos. Por outro lado, o novo regime, do Xá, não deveria atribuir monopólio à jovem National Iranian Oil Company, fruto do espólio britânico, o que confirmou o Irã como peso-pesado da economia do petróleo. Em menor ou maior grau a "moda nacionalizante" marcou presença no tema, mas, desta vez, sem fomentar grandes perturbações à ordem econômica internacional.

Há impressão de que os Estados Unidos não mais interpretariam as nacionalizações como sinal de rebeldia ou de simpatia pelo programa político soviético. Contudo, se o negócio era provocar Washington para que tomasse providências a favor dos produtores de petróleo o jeito foi arrumar outro método. O encontrado foi a cooperação intra-setorial com a fundação, em 1962, da Organização do Produtores e Exportadores de Petróleo (OPEP).

\section{A Fase de Conflitos com a OPEP}

Os anos 1960 marcam a decadência da produção petrolífera dos Estados Unidos, o aumento de seu consumo e o país deixa de ser exportador de óleo. Os motivos para isso são básicos: o Estado americano se responsabiliza pela maior parte do abastecimento do combustível utilizado nas máquinas da OTAN. Além disso, de 1950 a 1971, os Estados Unidos lideraram o período chamado era de ouro do capitalismo, em que a economia internacional havia crescido em ritmo acelerado e procurado espalhar ganhos para todo o mundo.

Com o petróleo correndo como prima dona da economia internacional, em boa fase, coube à OPEP militar por melhores condições financeiras aos países produtores. Afinal, era deles que o recurso energético mais importante da história era retirado. E os baixos preços considerados alimentava a queixa sobre a dualidade socioeconômica dos países produtores, em que a população mais pobre não usufruía dos lucros da grande riqueza.

A partir de 1965 começa um processo de contestação aos modos com os quais o preço internacional do petróleo é concebido, sem a relevante participação da OPEP. Boa parte das contestações caía sobre o Hemisfério Norte, notadamente, nos Estados Unidos, o maior consumidor de petróleo. 
Disso não se estranha, já que o país tenha ficado no centro do conflito que emergirá nos anos 1970, cujo impacto marca a história do capitalismo.

Em 1973 começa a crise cujo desfecho é considerado o ponto final da era promissora que vinha desde os anos 1950, bem como dos Estados Unidos como potência reguladora do regime econômico internacional fundado, em 1944, pelas instituições de Bretton Woods. Se a politização da energia era um fato no Egito e no Irã agora chegará a níveis dramáticos.

De acordo com leitura regular sobre o tema, Arábia Saudita e Irã lideraram boicote de petróleo aos Estados Unidos e Europa Ocidental, com irradiação aos países do Terceiro-Mundo não produtores que, por isso, foram prejudicados pela carestia das importações. ${ }^{17} \mathrm{O}$ motivo elencado para tanto foi o apoio que as potências ocidentais haviam dado a Israel na Guerra do Yom Kipur, em 1973, no qual os árabes militarmente perderam.

Ao procurar obter lucro político no desastre bélico os produtores de petróleo, membros da OPEP, forçaram o cartel a suspender o envio do carburante para aqueles que apoiaram o Estado judeu de alguma forma, que acabou abarcando os Países Baixos e Portugal. O efeito imediato do boicote foi a escalada de preço do barril de petróleo que em semanas pulou de 2,00 a 12,00 dólares. ${ }^{18}$ A multiplicação do valor do barril dava a entender que seria uma maneira de castigar os ocidentais pelo apoio ao inimigo e, ao mesmo tempo, propiciava um aumento de "poupança internacional" que de outra forma não existiria.

Os efeitos políticos e psicológicos da crise de 1973 se fez sentir mais nos Estados Unidos do que nas demais potências ocidentais. Isto porque a queda do governo Nixon, no mesmo ano, alimentava a ideia de que o país entraria em um inferno astral pela ausência de real projeto de poder que continuasse o expressado pelo ex-presidente republicano. As observações negativas da elite política e intelectual norte-americana se alimentavam da perda de capacidade industrial do país frente ao dinamismo alemão e japonês e, por vez, da dianteira que a União Soviética tivera em mísseis estratégicos continentais. ${ }^{19}$

A crise de percepção de poder atingiu fortemente o governo democrata de Jimmy Carter, de 1976 a 1979, que fora interpretado como "fraco" perante aos grandes desafios internacionais. Vale dizer, Carter não apresentava o punho forte dos antigos presidentes para europeus, asiáticos e soviéticos que desafiavam o poder americano em áreas que normalmente não deveriam. Apesar de tudo, sem entrar no mérito sobre a qualidade daquele governo, a Casa Branca instituiu comando que procurou manter destaque dos Estados Unidos em sensível região, a passagem do oceano Índico para o Pacífico.

Disso nasceu a Doutrina Carter que perdura até a atualidade, apesar de mudanças constantes. A doutrina pede, basicamente, que os Estados Unidos controlem o trânsito de navios mercantes e petroleiros por trechos e águas em que essas embarcações trafegam. O controle é feito por meio da Armada 
estacionada em estreitos, como Ormuz e Suez. Sobre a crise da OPEP esse controle não é sem propósito, pois ele representa uma media que Carter teve para demonstrar poder face a manifestações contrárias no Oriente Médio.

Para não sofrer boicotes ou uso político sobre o petróleo os Estados Unidos formularam planos de longo prazo que são desdobramentos da Doutrina Carter: contratar somente petroleiros registrados em países amigos e não produtores de óleo, Grécia e Panamá, e desmontar refinarias existentes nos membros da OPEP, forçando-os a exportar o cru e não os derivados. ${ }^{20}$ Outra artimanha da combinação anglo-americana foi concentrar as negociações de petróleo nas duas principais praças financeiras internacionais: Nova York e Londres. $^{21}$

Em 1979, mais uma situação política difícil, mas sem a dramatização de anos anteriores. Novamente o petróleo está no centro das atenções quando eclode a guerra entre o Irã e o Iraque. E mais uma vez os Estados Unidos estão presentes em alto grau. Falemos do Irã que fora revolucionado pelo movimento islâmico xiita do aiatolá Khomeini, para o qual o poder americano era o que de mais pernicioso haveria no mundo. Por outro lado, havia o Iraque governado pelo programa do nacionalismo árabe, o mesmo de Nasser, que fizera a cabeça do coronel Saddan Hussein para fazer do país uma potência regional.

$\mathrm{O}$ embate entre as duas potências petrolíferas concorrentes, uma pela islamização fundamentalista, a outra pelo nacionalismo secularista, promoveu forte elevação do preço do barril de petróleo que saiu do patamar de 12 dólares e bateu 40 dólares em 1979/80. ${ }^{22}$ Dessa vez, as potências ocidentais sofreram menos pela falta do recurso. Os Estados Unidos, por exemplo, conseguiram sobressair com reservas estratégicas para duração de um ano. A Europa Ocidental também se saíra bem por causa da aproximação político-econômica da União Soviética em busca de investimentos.

Por conseguinte, políticas nacionais e regionais concorreram para diminuir a influência da OPEP ou de conflitos bélicos no Oriente Médio sobre a economia do petróleo. Apenas para citar duas de grande dimensão: a exploração de novos campos no Alasca e a descoberta dos campos do Mar do Norte, que deram ao Ocidente um pouco de alívio; descanso que durou até 1991, quando novamente ocorre conflito envolvendo o Iraque.

\section{0: Anos de Calma com o Petróleo}

A fase de equilíbrio para o Hemisfério Norte se deu quando os Estados Unidos passam a explorar santuários ambientais do Alasca na metade dos anos 1980 - mesmo que rico em petróleo o estado ficava separado do programa de exploração por causa de dificuldades técnicas. O trabalho no Mar do Norte foi realização de três países, Grã-Bretanha, Países Baixos e Noruega, que no mesmo período de tempo, conseguiram grandes progressos. O resultado obtido pelas duas iniciativas fez com que a produção da OPEP ficasse em nível inferior às 
exploradas pelas potências ocidentais. Claro, por causa da guerra Irã e Iraque o estoque do cartel havia diminuído, mas apenas naquele período. ${ }^{23}$

O tempo de calmaria na economia do petróleo ajudou o insumo a ser cotado em torno de 3 e 4 dólares/barril na bolsa especializada de Nova York, a NYMEX. ${ }^{24}$ Também é lícito citar mais duas iniciativas que deram conforto ao Hemisfério Norte e arrefeceu politicamente o Oriente Médio. A União Soviética, importante produtora, jogara seu hidrocarboneto no Ocidente, com o intuito de fazer caixa em uma potência que apresentava dificuldades financeiras para suportar seu programa político e carecia de moeda forte. Entretanto, um paradoxo surtiu aqui, visto que Moscou necessitava da compra ocidental de seu petróleo e, ao mesmo tempo, o governo republicano de Reagan queria dobrar o poder soviético:

As seguidas pressões (...) dos Estado Unidos junto à Arábia Saudita ao longo dos anos 1980 para uma expansão da produção num momento caracterizado por recessão na Europa Ocidental objetivaram garantir preços baixos em troca de proteção e tecnologia, e, do mesmo modo, as pressões de expansão inglesa no mar do Norte fizeram parte dessa estratégia voltada para aumentar as dificuldades da economia soviética. ${ }^{25}$

Em outra instância, o Canadá também participa do jogo de forma "heterodoxa", a saber, sem ter relevantes jazidas de óleo leve, a exemplo dos árabes e russos, Ottawa ganha espaço com áreas betuminosas, óleo pesado, e gás natural da província de Alberta. Esses recursos podem ser revertidos em combustíveis para uso nos Estados Unidos, em primeiro plano. Seu deslocamento se dá por dutos, apesar do trabalho que exige e do custo ambiental. Todavia, em um sistema traumatizado por boicotes, a inconveniência operacional desses heterodoxos são superados pela busca de segurança energética.

Mais dois itens podem ser agregados, ainda que a participação deles na estabilidade acima seja indireta. Citemos os três primeiros anos de 1980 em que havia recessão internacional. Em clima de baixa econômica geralmente cai a queima de petróleo em todo o mundo. Também podemos dizer que o carvão mineral não saiu de moda. Apesar de ser considerado ultrapassado nos países industrializados seu uso nunca foi abandonado, e agora está sob pesquisa para extrair dele elementos poluentes para transformá-lo em combustível regular, sem provocar grandes danos ambientais, como retrata Yergin. ${ }^{26}$

A passagem dos anos 1980 para a próxima década marcará o fim do equilíbrio que permitiu às potências ocidentais programas pertinentes à produção petrolífera que pudesse ser superior a da OPEP. A União Soviética começa a fazer água e desregula sua função dominadora na Europa Oriental. Por causa disso, um rol de conflitos e guerras menores ocorrerão na zona do 
antigo socialismo soviético, eis a guerra da ex-Iugoslávia que durou quase dez anos. Mas o acontecimento mais importante será a anexação manu militari que o Iraque, de Saddam, fará com o monarquista Kuwait, misturando a política regional.

Isto porque os árabes não caminharão juntos, mesmo que tenha havido pontos em comum entre eles, como a filiação na OPEP. A Arábia Saudita, depois de se remoer diplomaticamente, declara sua negação a Bagdá em favor do vizinho anexado e sede seu espaço para a logística de guerra dos Estados Unidos. O antigo inimigo, Irã, prefere a neutralidade, bem como a Síria e o Egito. A Guerra do Golfo será um embate de vários significados, inclusive petróleo.

\section{A Guerra do Golfo e os Anos 1990}

Dentro de uma interpretação, a formação de aliança sob liderança dos Estados Unidos, Tempestade no Deserto, só foi possível por causa do fim da União Soviética que não podia expressar vontade para impedir que Washington conjugasse ataque ao Iraque em fevereiro de 1991. Em agosto de 1990 as forças iraquianas invadem o Kuwait e o declaram a última providência do país. Isto porque historicamente o território kuaitiano pertencera ao Iraque. Sua transformação em Estado independente fora obra da Grã-Bretanha, na qualidade de unidade tampão, para contrabalançar forças divergentes no Oriente Médio.

Além de não ter que concorrer com a oposição soviética os Estados Unidos ainda contaram com a anuência das Nações Unidas, onde o Conselho de Segurança aprovou, com neutralidade da China, a entrada dos liderados norte-americanos na região de conflito. A justificativa foi a de restaurar a independência do Kuwait e de se fazer valer a letra do direito internacional, a da autodeterminação dos povos. Mas outras razões poderia haver nisso.

Um dos motivos para a entrada dos Estados Unidos na guerra do Iraque seria a necessária ação militar para que Hussein não utilizasse os recursos do petróleo para a melhoria militar do Iraque, na aquisição de equipamentos de alta tecnologia. A saber, contra o objetivo de Bagdá de fazer do país uma potência com poder para sobressair aos concorrentes regionais. Além do mais, havia o receio de haver um centro regulador de energia no Oriente Médio, caso o Iraque lograsse sucesso em sua empreitada político-militar. ${ }^{27}$

Sob um aspecto, o jogo intencionado pelos Estados Unidos não era desconhecido. O mesmo havia feito a Grã-Bretanha, desde os anos 1850, fazendo com que uma potência europeia não tivesse facilidade para sobressair às outras, mantendo o tradicional princípio do equilíbrio de poder. Em parte, para Henry Kissinger, a política americana já exercitara ação semelhantes, desde 1971, ao privilegiar a China contra a União Soviética ou dar atenção à Índia para que ela se tornasse uma terceira força na Ásia - dividir para reinar. ${ }^{28}$ 
Em todo caso, não se pode deixar de verificar que naquela guerra havia também a presença do petróleo. Para um lado, os Estados Unidos e o Ocidente adentraram no Iraque para impedir que Hussein se apossasse de importante reserva e a acrescentasse às iraquianas. Caso esse fito fosse realizado daria ao Iraque uma preeminência econômica e projeção de poder que dificilmente seria ombreada por outras potências, caso do Irã ou da Síria.

Por outro lado, se originalmente os aliados ocidentais fossem movidos por interesses humanitários, em restaurar a independência do Kuwait, ou por garantir o suprimento de energia ao Hemisfério Norte, talvez impulsionados por princípios egoístas, conforme apontam alguns críticos, isso não secundaria o papel do petróleo tanto em um caso como no outro. O ouro negro foi elemento central daquela guerra, seja para legalistas ou realistas.

Depois de breve batalha as forças iraquianas capitularam, mas sem deixar de fazer algo de impacto. Como forma de retaliar a economia mundial de petróleo Bagdá ordenou que os poços fossem incendiados, o que ocupariam os Estados Unidos para reordenar a região. E, em outra instância, Hussein se manteve com o mínimo de poder para imprimir controle territorial e afastas forças a ele hostis, como as constituídas por curdos e xiitas.

Com o fim da Guerra do Golfo passou a ser vinculado na imprensa internacional que haveria uma nova ordem mundial, que esse reordenamento seria resultado da conjugação norte-americana que sobressairia a todos os desafios e não deixaria nenhum tipo de vazio de poder. Quer dizer, com o fim da União Soviética, a falta de projeção suficiente da China e a apatia da União Europeia, os Estados Unidos podiam alegar que eles seriam os guardiões da nova ordem; que nenhuma outra potência teria condições de negar isso.

No sistema internacional de energia a combinação Nova York-Londres concluiu processo que havia começado em 1971, no governo Nixon, no desregulamento dos mercados de petróleo e, ao mesmo tempo, centralizar a formação de preços nas duas grandes sedes financeiras internacionais. Neste ponto, o que vingaria não seria o cálculo de custos ou de operações de extração do bem, conforme se adotava regularmente, mas a pertinência que o petróleo teria para o futuro próximo na perspectiva dos bancos de investimento:

Esta tendência é em parte devida, pelo menos a curto prazo, à distância desusada do mercado petrolífero dito em contango, isto é, com contratos futuros oferecendo um preço do barril a prazo mais alto do que o preço em contado (...). É evidente que isso traduz a inquietação dos operadores em relação à fraqueza da oferta de crude e de produtos perante a procura futura. ${ }^{29}$

Especulação, racionalização, mercado de futuro são termos que vieram a brindar a premissa, controversa, de que na atualidade só se pode dizer que 
a OPEP expressa poder substancial se for por simpatia aos seus membros solidariedade ao antigo Terceiro Mundo ou coisa que o valha. No fundo, quem realmente congrega a economia do petróleo, e sua valorização, é o eixo Nova York-Londres. Os Estados Unidos continuam na dianteira. ${ }^{30}$

No aspecto empresarial, ligado ao poder político dos Estados Unidos e das potências ocidentais, houve progresso na "oligarquização" do mercado doméstico e mundial em razão de fusões que ocorreram nos anos 1990 e nos 2000. Petroleiras maiores compraram menores dentro do próprio país e no estrangeiro. A Exxon adquiriu a Mobil; a Conoco, a antiga Standard da Califórnia comprou a Phillips. Em 2004 o Departamento de Justiça em Washington bloqueou a fusão da americana Unocol pela companhia estatal da China. ${ }^{31}$

O que estava em jogo não era a pureza de doutrinas, liberais ou intervencionistas pelo poder público (debate considerado puramente acadêmico pelas empresas) mas sim a continuidade de um processo de conservação do regime internacional da energia sob coordenação dos Estados Unidos e da Grã-Bretanha. A Anglo-holandesa Shell trabalha sob os auspícios da Casa Branca, o mesmo vale para a espanhola Repsol.

Algumas firmas rebeldes, por causa do histórico de crítica diplomática de seus países, caso da francesa Total e da Italiana Agip não contrariam desmedidamente suas homônimas ocidentais quando se trata de novas buscas. O motivo pode ser encontrado na premissa de que o pior é a ser enfrentado não está no Oeste, mas sim no Leste, com a agressividade de russos, recém enriquecidos, e Chineses que competem a passos largos pelo maná. ${ }^{32}$

Aqui abre-se uma perspectiva. Não seria erro afirmar que, na atualidade, os Estados Unidos passam por conforto energético na medida em que não depende em grande parte de importações, sobretudo de países considerados hostis a Washington, como parte do Oriente Médio. No lugar da Arábia Saudita a economia americana espera mais importação do Canadá ou do México vizinhos historicamente presos ao interesse americano. ${ }^{33}$

Além do mais, não seria equivocado dizer que uma revolução energética ocorre nos Estados Unidos, ainda que possa haver interpretações conflitantes do que vem a ser essa revolução. O gás de xisto, de Marcellus Shale, dando ao país um superávit poucas vezes visto, mais as renovadas explorações do Golfo do México e das reservas do Alasca, são componentes fundamentais da segurança energética norte-americana para este tempo. ${ }^{34}$

Isto significa que o poder americano se descuidaria da economia internacional do petróleo por causa de seu relativo conforto? Certamente isso não aconteceria em virtude de duas situações: a economia capitalista, como se apresenta, não é divorciada do petróleo regular; cuidar dos hidrocarbonetos mundiais é também tarefa dos Estados Unidos, uma vez que o bem-estar dos países amigos, principalmente os da OTAN, são um 
adendo à posição dos Estados Unidos como potência hegemônica nesse sistema internacional.

Neste momento, os Estados Unidos voltam a ser os maiores produtores mundiais de petróleo, superando a Arábia Saudita e Rússia. ${ }^{35}$ Claro que essa posição pode virar, uma vez que a produção saudita atender a conveniências políticas da OPEP, às vezes baixando a produção para angariar preço. Em todo caso, não deixa de ser algo que representa a fertilidade econômica norteamericana em insumo tão complexo e presente na moderna civilização material.

\section{Considerações Finais}

Sob determinada leitura da economia internacional o Hemisfério Norte, industrializado, assim se tornou por causa do petróleo. Se a Revolução Industrial do século XVIII ganhou vida foi por causa do carvão mineral. Da mesma forma, se houve continuação desse processo revolucionário o responsável foi o petróleo. O carvão fez a Grã-Bretanha ser grande potência em sua era; o mesmo se aplica com o petróleo na política dos Estados Unidos. Contudo, há um imbróglio de difícil resolução: essas potências são decadentes em óleo.

Dentro desse prisma, de onde vem o fluxo energético que permite os Estados Unidos, por exemplo, serem o que são, a não ser as reservas estrangeiras, as dos países em desenvolvimento? Nesse quadro José W. Bautista Vida e Gilberto Vasconcellos acreditam que a clivagem Norte-Sul dos anos 1970 não arrefeceu. Ela continua pelo motivo de que o Hemisfério Norte não tem petróleo suficiente para manter a atividade econômica aquecida e necessita adentar ao antigo Terceiro-Mundo para se abastecer. E o nome dessa intromissão é a violência, o neocolonialismo que os autores acreditam existir. ${ }^{36}$

Neste século, até o momento, não há sinais claros de que devem surgir correntes desestabilizadoras da política internacional de coloração tradicional ou conhecida, Estados opositores ou organizações, como a OPEP. É hipótese distante haver outra conjugação crítica como a de 1973. Já algo parecido com o embate de 1979 é menos difícil. Mesmo que os Estados Unidos não gozem de simpatia irrestrita no sistema internacional isso não significa que Rússia, Índia ou China sejam indiferentes a possíveis ataques terroristas.

A razão para isso é que tais ataques que pudessem ocorrer em jazidas de petróleo, refinarias na bolsa de valores criaria pânico e desânimo, cujo desfecho não seria bom para ninguém. Podemos dizer que, embora as potências sejam concorrentes em diversos itens, no campo do petróleo o que vale é a estabilidade, ainda que o maior beneficiário sejam os Estados Unidos. Aqui não se trata de solidariedade, mas de pragmatismo, uma vez que a economia americana ainda corresponde por $20 \%$ do PIB mundial.

Deste modo, se existe uma economia em rede ela responde pela relação estreita entre os Estados Unidos, Europa Ocidental e demais potências asiáticas. $\mathrm{O}$ abalo no fluxo regular de energia para uma delas, por questões de disputa 
política, afeta a relação de ganho de todas elas. E nos dias de hoje o que o mundo quer é paz para ganhar dinheiro e, se possível, dar emprego, alimentar o consumo e evitar que haja crises anti-sistêmicas.

\section{Notas}

1 José Alexandre Altahyde Hage é doutor em Ciência Política pela Unicamp e professor do Depto. de Relações Internacionais da Unifesp, onde leciona Geopolítica e Questões Estratégicas Contemporâneas. E-mail: alexandrehage@hotmail.com

2 Referimos ao característico empresário americano, o self-made man, que faz fortuna de modo estranho ao tradicional capitalista europeu. Na visão de Galbraith seriam homens destemidos e de frouxa moral que para chegarem ao objetivo passam por todos os obstáculos e se tornam milionários. John D. Rockfeller, Cornelius Vanderbilt e J. P. Morgan, respectivamente, petróleo, ferrovias e bancos inaugurariam a exclusiva classe de milionários no final do século XIX, um típico produto norte-americano. GALBRAITH, John Kennedy. A Era da Incerteza. São Paulo, Pioneira, 1981.

3 YERGIN, Daniel. Petróleo. São Paulo, Editora, Scritta, 1994.

4 Claro que em momento posterior houve o emprego do carvão mineral para iluminação, porém menos utilizado que no Reino Unido, o carburante rapidamente foi trocado pela novidade advinda do petróleo, mais barato e prático.

5 LEVINE, Steve. O Petroleo e a Glória. São Paulo, Editora Landscape, 2007.

6 A lei do senador Sherman não foi concebida especialmente para a Standard Oil. Seu papel foi para neutralizar todas as iniciativas empresariais que chegassem ao monopólio, seja petróleo, tabaco ou açúcar. A relação quase automática entre a Lei Sherman com a Standard se deve, em grande parte, às campanhas políticas e publicitárias que havia contra a empresa. A mais conhecida militante da ação foi Ida Tarbell, cujo pai teve empresa comprada por Rockfeller em condições aviltantes.

7 YERGIN. Opus cit.

8 YERGIN. Opus cit idem. Pg. 172

9 HOBSBAWN, Eric. A Era dos Extremos. São Paulo, Editora Companhia das Letras, 1994.

$10 \mathrm{Na}$ atualidade há iniciativas de se utilizar madeira para geração de calor. Porém, tratase de matéria tratada para tal uso e não desflorestamento. O que nos ferimos como algo atrasado em partes do Hemisfério Sul é a queima de madeira original.

11 Os nomes podem mudar em virtude das circunstâncias econômicas e políticas. Mas para efeito de informação as Sete Irmãs eram empresas que saíram da pulverização da Standard ou o ingresso de internacionais na família. São elas Esso, Texaco, Mobil, Gulf, Standard, Shell e British Petroleum (BP). A Shell é fruto de empreendimento anglo-holandês, o maior concorrente dos Rockfeller antes da Segunda Guerra. A BP nasce como empresa estatal britânica, em 1909, anteriormente Anglo-Persian Oil Company, com o direito de explorar o óleo da Pérsia, depois Irã. A empresa foi privatizada em 1981 no programa do governo Thatcher.

12 Embora a Royal Dutch Shell seja uma empresa de duas administrações, uma em Londres, o lado que mais pesa é o holandês. Por isso, nos anos 1930 seu presidente Henri Deternig provocou desconfiança na política britânica por causa de sua aproximação do Partido Na- 
zista alemão. Até onde foi a simpatia do executivo é algo em aberto. Em todo caso, isso deu razão aos criadores da BP que pensavam uma empresa independente.

13 MELLO, Leonel Itaussu. Quem tem Medo da Geopolítica? São Paulo, Editora Hucitec, 1999.

14 TORRES FILHO, Ernani. "O Papel do Petróleo na Geopolítica Americana”. In FIORI, José Luís (org). O Poder Americano. Petrópolis, Editora Vozes, 2004. Pg. 308.

15 Ainda que o Brasil fosse marginal na questão dos nacionalismos do Oriente Médio é lícito dizer que houve influência daquelas manifestações nas políticas nacionalistas no segundo governo de Getúlio Vargas e no de Juscelino Kubtischek. A própria criação da Petrobras, em 1953, foi pensada no clima de dar ao Brasil instrumentos de soberania, de posse do petróleo, em face da pressão exercida pelas grandes potências e suas petroleiras, conforme pensavam militares nacionalistas, sobretudo os do Exercito, para quem o país não se credenciaria como potência respeitável se não controlasse o empreendimento de seus recursos naturais. Da mesma forma, em 1958, houve iniciativa de se fazer parceria comercial entre o Brasil e a Bolívia para que o primeira diminuísse as importações do Oriente Médio para evitar impasses sobre os quais não tinha controle. Na atmosfera otimista para princípios de cooperação regional, vide a Operação Pan-Americana, a ideia era boa, mas não vingou como se desejava. HAGE, José Alexandre. Bolívia, Brasil e a Guerra do Gás. Curitiba, Juruá, 2007.

16 ARON, Raymond. Paz e Guerra entre as Nações. Brasília, Edunb, 1986.

17 Regular porque há autores que diversificam os motivos que levaram à crise da OPEP. Peter Gowan demora na análise sobre o tema e pensa que aquele conflito foi justamente produzido pelo poder americano com anuências das casas reais saudita e iraniana, não houve surpresas. A razão para tanto, para Peter Gowan, foi a procura de forçar perda de competitividade da Alemanha Federal, do Japão e barrar o crescimento do Terceiro Mundo em via de industrialização, caso de Brasil, Índia e México. GOWAN, Peter. A Roleta Global. Rio de Janeiro, Editora Record, 2003.

18 GOWAN. Opus cit.

19 Embora o boicote de petróleo não tenha mirado os países do Terceiro Mundo seus efeitos foram bastante sentidos em muitas unidades dessa denominação. Isto ocorreu no Brasil que teve de aumentar sua dívida externa para importar mais petróleo, uma vez que não havia produção suficiente no país para dar cabo da demanda. Por outro lado, o governo da época, de Ernesto Geisel, aproveita a crise da OPEP para lançar programa que levasse em conta a busca da autossuficiência, além da criação do programa de álcool combustível . VIDAL, José W. Bautista. VASCONCELOS, Gilberto. O Poder dos Trópicos. São Paulo, Editora Casa Amarela, 1998.

20 CONANT, Melvin. GOLD, Fern. A Geopolítica Energética. Rio de Janeiro, Bibliex, 1981.

21 GOWAN. Opus cit idem.

22 YERGIN. Opus cit idem ibdem.

23 SANTOS, Edmilson Moutinho dos. "Petróleo - Quadro Estratégico Global no Início do Século XXI”. In Política Externa. Volume 12, número 1.São Paulo, USP/Paz e Terra, 2003.

24 Somente como referência, a bolsa específica na cotação do petróleo é a NYMEX e não a de Wall Street, como se pode pensar. É fato que a primeira não se limita a cotar somente petróleo, mas o peso que o insumo tem faz com que a instituição se confunda com o carburante. Já em Londres o petróleo é cotado na City sob a legenda Brent. 
25 FIORI, José Luís. MEDEIROS, Carlos. SERRANO, Franklin. O Mito do Colapso do Poder Americano. Rio de Janeiro, Editora Record, 2008. Pg. 28.

26 YERGIN, Daniel. A Busca. São Paulo, Editora Intrinseca, 2014.

27 PORTO, Mauro. O Crepúsculo do Petróleo. Rio de Janeiro, Editora Brasport, 2006.

28 KISSINGER, Henry. Diplomacia. Lisboa, Editora Gradiva, 2007.

29 SÉBILLE-LOPEZ, Geopolíticas do Petróleo. Lisboa, Instituto Piaget, 2006. Pg. 28.

30 SÉBILLE-LOPEZ. Opus cit.

31 É ilustrativa essa passagem quando verificamos que nos Estados Unidos não há, regularmente, empresas estatais de energia. No senso-comum, a sociedade norte-americana não é contrária à entrada de empresas internacionais de petróleo no país, mesmo que elas seja estatais, tanto que lá trabalham a Petrobras e a venezuelana PDVSA. Por outro lado, tudo isso ocorre desde que não contrarie a linha diretora do poder central sobre tema que certamente não há espaço para contemporização. No final das contas a ultima palavra fica em Washington.

32 No Brasil o efeito da influência internacional deu-se em 1997 com o fim do monopólio nacional do petróleo, instituído em 1953. Em 1997, com regra mais liberal, o governo Fernando Henrique Cardoso passa a permitir a entrada de petroleiras estrangeiras para operar com a estatal brasileira sob regime concessão, mais apropriado, do ponto de vista empresarial para aquele momento, uma vez que no país não havia sido descoberta as jazidas da Bacia de Santos, do pré-sal. Porém, a partir de 2008, no governo Lula da Silva, houve a substituição daquele regime jurídico pelo de partilha, este, considerado apropriado para países cujo risco econômico para extrair o insumo é baixo, portanto benéfico para os investimentos em geral. Além do mais, a partilha também foi interpretada como medida concernente a um governo que procurava reforçar o poder político sobre os empreendimentos privados, domésticos ou internacionais. De certa forma, o governo Lula havia procurado lembrar o ideário nacionalista de Getúlo Vargas, para o qual o controle das matérias-primas estratégicas seria meio para fazer do Brasil uma potência relevante. HAGE, José Alexandre Altahyde. "Regimes Regulatórios e Política Internacional" In Ideias. №3, nova série. Campinas, Universidade Estadual de Campinas, 2011.

33 Saber se a guerra de 1991, bem como a de 2003, II Guerra do Golfo, foi pela apropriação de petróleo é algo que beira a controvérsia. Isto porque a dependência do Estado americano ao petróleo do Oriente Médio não questão conclusiva. Os maiores parceiros dos Estados Unidos não são majoritariamente da OPEP. A liderança norte-americana na derrubada de Saddam Hussein teve o objetivo, entre outras coisas, de liberar o petróleo iraquiano para os aliados de primeira hora, que não contestaram a iniciativa da Casa Branca para aquela guerra. Lembremos da fala do presidente George W. Bush, para quem havia duas Europas. A Nova Europa, Espanha, Reino Unido e Polônia era aquela que compreendia as razões dos Estados Unidos de fomentarem mudanças violentas no Oriente Médio; ao contrário da Velha Europa, notadamente França e Alemanha que não apoiavam a demanda de Washington. Uma amostra de "gratidão" dos Estados Unidos à Velha Europa, ao adentrar no Iraque, foi permitir a participação de petroleiras espanholas, britânicas e polonesas naquele país. Não devemos ignorar o peso do petróleo nas ações de Bush e Tony Blair, mas também não devemos negligenciar apelos domésticos que aqueles dois governos procuraram atrair para fundamentar seus poderes: de conservar para a sociedade a ideia dos Estados Unidos como grande potência; bem como a noção, para a população britânica, de que o Reino Unido ainda podia influenciar grandes decisões internacionais. GOWAN, Opus cit idem, ibdem. 
34 YERGIN, Opus cit. 2014.

35 PETRONOTÍCIAS. Canadá Bate Recorde de Exportação para os Estados Unidos. 13 de abril de 2016. Site eletrônico encontrado em https://www.petronoticias.com.br/archives/82147. Consultado em 26 de maio de 2017.

36 VIDAL e VASCONCELLOS. Opus cit.

Recebido em 06/04/2017

Aprovado em 02/11/2017 